\title{
Analysis of the 1/20 translocation in ram spermatozoa by flow cytometry
}

\author{
H Lewalski ${ }^{1}$, FJ Otto ${ }^{2}$, T Kranert ${ }^{3}$, B Glahn-Luft ${ }^{1}$, R Wassmuth ${ }^{1}$ \\ 1 Institut für Tierzucht und Haustiergenetik der Justus-Liebig-Universitaet, Gießen; \\ ${ }^{2}$ Abteilung für Experimentelle Tumorforschung der Fachklinik Hornheide, Muenster; \\ 3 Strahlenzentrum der Justus-Liebig-Universitaet, Gießen, Germany
}

(Proceedings of the 9th European Colloquium on Cytogenetics of Domestic Animals; Toulouse-Auzeville, 10-13 July 1990)

unbalanced ram spermatozoa / flow cytometry / 1/20 translocation

\section{INTRODUCTION}

Structural rearrangements of chromosomes, including translocations can have adverse effects on fertility in humans (Daniel, 1988; Lange et al, 1990) and animals (Gustavsson, 1980; Eldridge, 1985; Daniel, 1988). The formation of unbalanced gametes during meiosis in heterozygous translocation carriers may cause unbalanced embryos which fail to survive to the implantation stage of pregnancy or die in later stages of development.

In sheep, two different translocations are known. Bruère et al (1974) observed 3 types of Robertsonian translocations designated Massey I (5/26), II (8/11) and III $(7 / 25)$, but reproduction of carriers was not negatively affected by the translocations (Bruère, 1975; Long, 1977, 1978; Bruère and Ellis, 1979). Long (1977) and Bruère et al (1981) concluded that a selection mechanism in heterozygous translocationcarrying rams during spermatogenesis eliminates unbalanced secondary spermatocytes.

On the other hand, carriers of the $1 / 20$ translocation showed a reduction in fertility (Glahn-Luft and Wassmuth, 1980, 1985). These results led to the assumption that heterozygous $1 / 20$ translocation carriers produce unbalanced gametes causing early embryonic mortality.

A method to confirm the existence of unbalanced gametes is the measurement of their DNA content. Flow cytometry has been used to measure the relative DNA content of X and Y chromosome-bearing sperm populations (Otto et al, 1979; Garner et al, 1983, Johnson, 1987) as well as to demonstrate chromosomal rearrangements in spermatids of mice carrying the Cattanach translocation (Meistrich et al, 1979). 


\section{MATERIALS AND METHODS}

Freshly ejaculated semen was collected from heterozygous $1 / 20$ translocation carriers as well as presumed non-carriers of various sheep breeds. The samples were prepared for flow cytometric analysis as described by Otto et al (1979). Suspensions of stained sperm nuclei were measured using a PAS II flow cytometer (Partec AG, Arlesheim, Switzerland).

\section{RESULTS AND DISCUSSION}

The histogram of spermatozoa from a normal ram shows a distinct separation of $\mathrm{X}$ and $\mathrm{Y}$ chromosome-bearing spermatozoa (fig 1). The analysis revealed a difference of $4.5 \%$ in the DNA content of gonosomes and a ratio of $48 \% \mathrm{Y}$ and $52 \% \mathrm{X}$ spermatozoa.

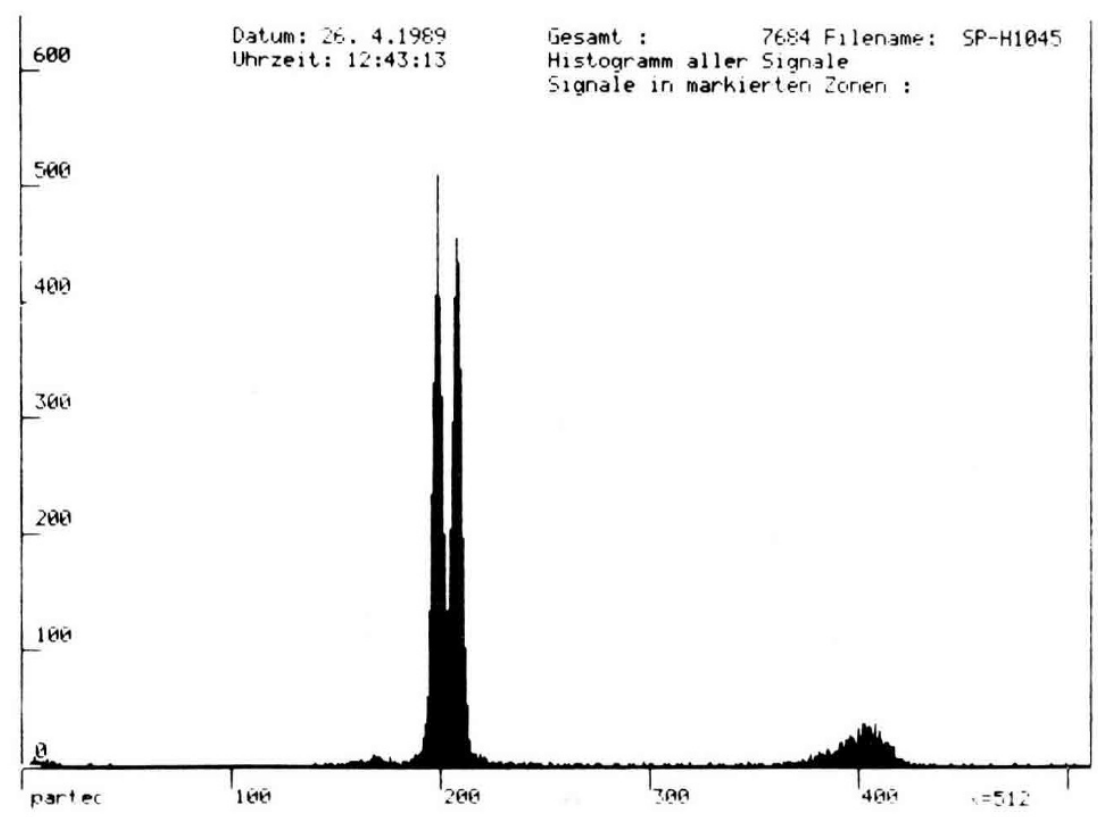

Fig 1. Flow cytometric DNA histogram of 4,6-diamino-2-phenylindol (DAPI)-stained ram spermatozoa. $C V=1 \%$. Abscissa: relative fluorescence related to the amount of DNA per chromosome; ordinate: relative number of chromosomes per channel.

The $1 / 20$ translocation involves the breakage of the distal part of the short arm of chromosome 1 and its transfer to the distal part of chromosome 20 (Glahn-Luft and Wassmuth, 1984). Considering alternate and adjacent chromosome 1 segregation at diakinesis, heterozygous $1 / 20$ translocation-carrying rams are expected to produce $\mathrm{X}$ and $\mathrm{Y}$ chromosome-bearing spermatozoa with reduced, normal, unchanged and 
increased DNA content. The resulting ratio of the different spermatozoa fractions is 1:2:1:1:2:1, which implies that 50\% normal or balanced and $50 \%$ unbalanced spermatozoa are ejaculated by heterozygous $1 / 20$ translocation-carrying rams. Due to the relative size of the translocated chromosomal fragment (approximately $2 \%$ ) and the expected ratio of sperm populations, it was possible to construct an empirical histogram using individual Gaussian curves. The histogram shows 5 instead of the expected 6 peaks (fig 2). This is due to the size of the translocated segment, since $\mathrm{Y}$ sperm with an increased and $\mathrm{X}$ sperm with a reduced DNA content merge between the 2 main peaks of $\mathrm{X}$ and $\mathrm{Y}$ spermatozoa which contain normal and balanced sperm.

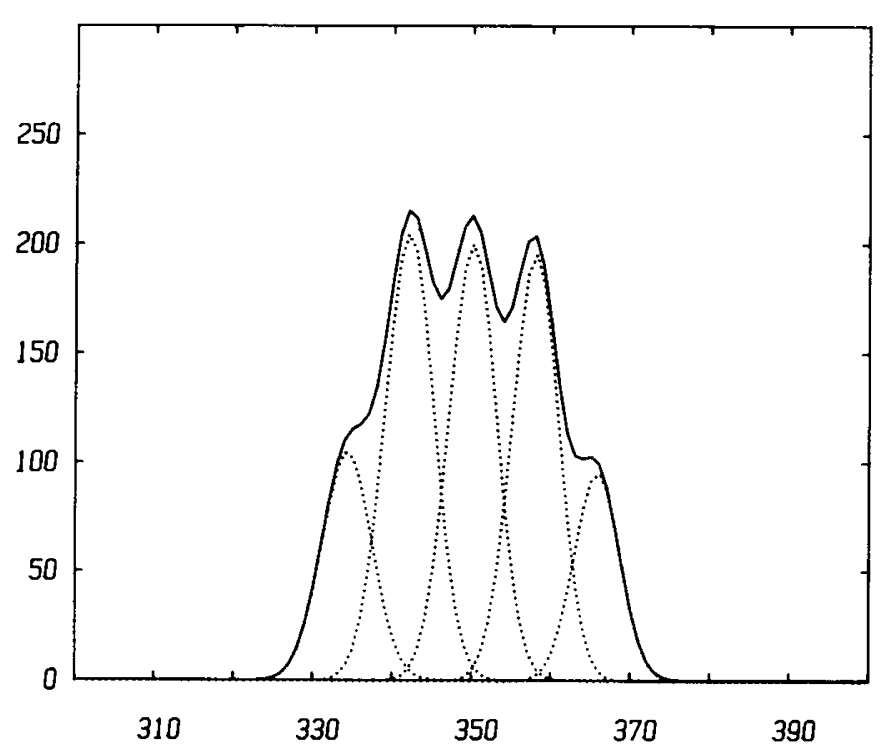

Fig 2. Predicted DNA histogram of spermatozoa from a heterozygous $1 / 20$ translocationcarrying ram.

In agreement with the calculated histogram, the flow cytometric analysis of ejaculated sperm from the 1/20 translocation-carrying ram 7402 also revealed 5 peaks (fig 3 ), demonstrating the existence of unbalanced spermatozoa. The ratio of individual sperm fractions as well as the positions of the peaks are in concordance with our theoretical calculations.

Using flow cytometry, the production of unbalanced spermatozoa by heterozygous $1 / 20$ translocation-carrying rams was confirmed. To determine whether this indeed has a negative effect on reproduction through the formation of unbalanced zygotes and embryos, further work will be necessary on selectively bred animals using cytogenetic methods. It may also be that spermatozoa with chromosomal defects are impaired to an extent which makes fertilization impossible. 


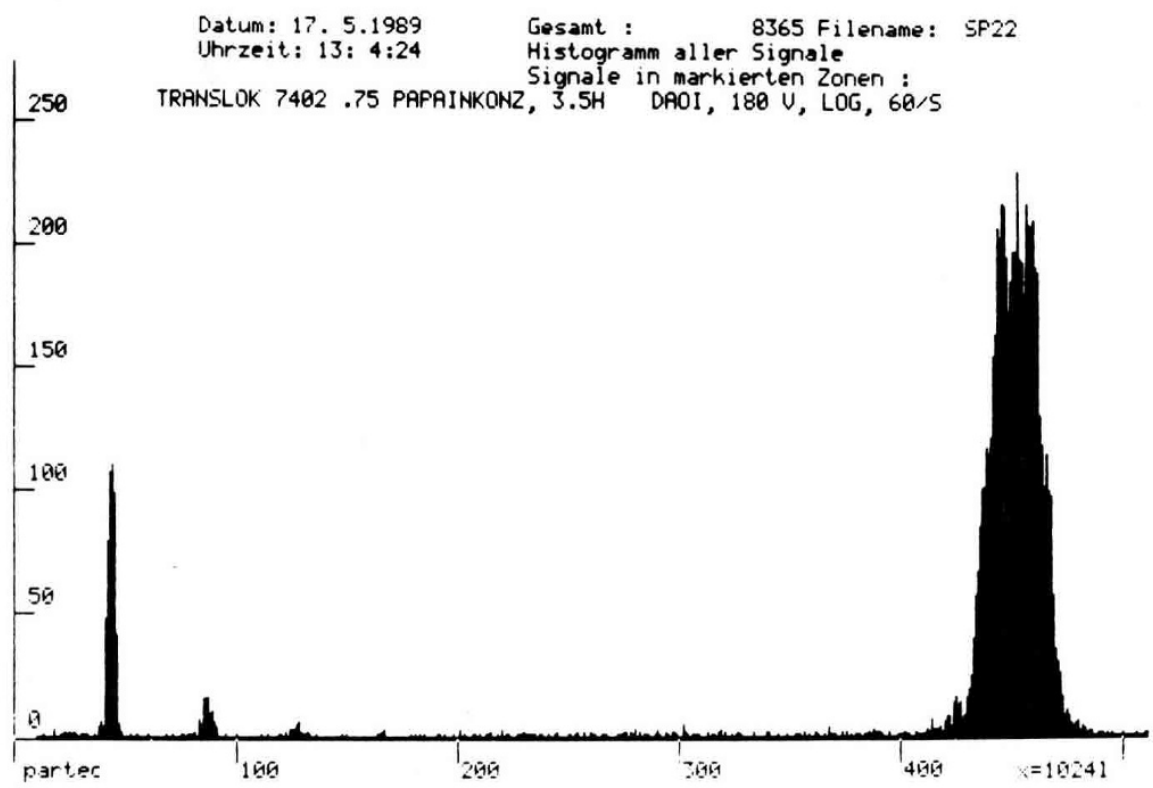

Fig 3. Flow cytometric DNA histogram of DAPI-stained sperm nuclei from the $1 / 20$ translocation-carrying ram 7402 . $C V=0.6 \%$. Abscissa: relative fluorescence related to the amount of DNA per chromosome; ordinate: relative number of chromosomes per channel.

\section{REFERENCES}

Bruère AN (1975) Further evidence of normal fertility and the formation of balanced gametes in sheep with one or more different Robertsonian translocations. $J$ Reprod Fertil $45,323-331$

Bruère AN, Ellis PM (1979) Cytogenetics and reproduction of sheep with multiple centric fusions (Robertsonian translocations). J Reprod Fertil 57, 363-375

Bruère AN, Zartman DL, Chapman HM (1974) The significance of the G-bands and C-bands of three different Robertsonian translocations of domestic sheep (Ovis aries). Cytogenet Cell Genet 13, 479-488

Bruère AN, Scott IS, Henderson LM (1981) Aneuploid spermatocyte frequency in domestic sheep heterozygous for three Robertsonian translocations. J Reprod Fertil 63, 60-66

Daniel A (1988) The Cytogenetics of Mammalian Autosomal Rearrangements. Alan R Liss, Inc, New York

Eldridge FE (1985) Cytogenetics of Livestock. AVI Publ Co, Westport, CT

Garner DL, Gledhill BL, Pinkel D, Lake S, Stephenson D, Van Dilla MA, Johnson LA (1983) Quantification of the X- and Y-chromosome bearing spermatozoa of domestic animals by flow cytometry. Biol Reprod 28, 312-321

Glahn-Luft B, Wassmuth R (1980) The influence of $1 / 20$ translocation in sheep on the efficiency of reproduction. 31st Annual Meeting of the European Association for Animal Production, München, 1-4 September 1980 
Glahn-Luft B, Wassmuth R (1984) Auswirkungen der 1/20 Translokation beim Schaf: Verminderte Fruchtbarkeit durch Chromosomenanomalie. In: Gießener Schriftenreihe Tierzuchl und Haustier-genelik, Band 47. Verlag Paul Parey, Hamburg

Glahn-Luft B, Wassmuth R (1985) Fetoproteinbestimmung bei Schafen mit heterozygoter Translokation. Zuchthygiene 20,5-8

Gustavsson I (1980) Chromosome aberrations and their influence on the reproductive performance of domestic animals - a review. Z Tierzüchtg Züchtgsbiol 97, 176-195

Johnson LA (1987) Separation of X- and Y-chromosome bearing mammalian sperm by DNA content using flow cytometric analysis and sorting. Biol Reprod 36 (suppl 1), 80

Lange R, Michelmann HW, Engel W (1990) Chromosomale Ursachen der Infertilität beim Mann - Eine Übersichtsarbeit. Fertilität 6, 17-28

Long SE (1977) Cytogenetic examination of preimplantation blastocysts of ewes mated to rams heterozygous for the Massey I $\left(t_{1}\right)$ translocation. Cytogenet Cell Genet 18, 82-89

Long SE (1978) Reproductive performance of ewes mated to rams heterozygous for the Massey I ( $\left.\mathrm{t}_{1}\right)$ centric fusion (Robertsonian) translocation. Vet Rec 102, 399-401

Meistrich ML, Göhde W, White RA, Longtin JL (1979) 'Cytogenetic' studies of spermatids of mice carrying Cattanach's translocation by flow cytometry. Chromosoma 74, 141-151 Otto FJ, Hacker U, Zante J, Schumann J, Göhde W, Meistrich ML (1979) Flow cytometry of human spermatozoa. Histochemistry 61, 249-254 